\title{
A multilevel analysis of work-life balance practices
}

\author{
Vui-Yee Koon (iD) Sunway University, Malaysia
}

\begin{abstract}
The current study uses a multilevel analysis to examine how work-life balance (WLB) practices applied at the organizational level associate with WLB practices and performance appraisal at the individual level that affects employee commitment, underpinned by the theory of supportiveness and the relational perspective. Respondents were 319 employees and 74 managers from small and medium-sized enterprises (SMEs) of various industries in Malaysia. Results indicate that the consistency of employee perception of WLB practices and performance appraisal at individual level influence employee commitment, whereas WLB practices at the organization level have a negative influence on employee commitment. The study also found differences in perception of WLB practices between managers and employees but a high level of WLB practices agreement. The current study provides a plausible explanation that the WLB practices undertaken by the organization may not be accessible or perceived by employees, thus affecting their commitment.
\end{abstract}

Keywords: employee perception, multilevel analysis, work-life balance
Key Points
1 Interaction of difference level within organization affects employee commitment.
2 Employee perception of HR practices implemented in the organization secures stronger effects on employee commitment.
3 Answered the call for research to investigate the employer-employee perceptions of HR practices.

\section{Introduction}

The practice of work-life balance (WLB) in an organization is often seen as a benefit to employees. WLB practice is an HR activity that employers can use to attract and/or retain talented people (Mescher, Benschop and Doorewaard 2010) and it includes flexible work arrangements, organizational support such as childcare services, and personal or family leave (McDonald, Brown and Bradley 2005). WLB practices have been actively studied

Correspondence: Dr Vui-Yee Koon, Department of Management, Sunway University, No. 5, Jalan Universiti, Bandar Sunway, 47500 Subang Jaya, Selangor, Malaysia; e-mail: vuiyeek@ gmail.com

Accepted for publication 23 May 2020. 
both in academic research and organizational business practice (Mescher, Benschop and Doorewaard 2010) but they have been mostly examined in an American context (Eby et al. 2005). As such, these previous findings might not be generalizable to other countries, particularly those outside of the United States (Shaffer, Joplin and Hsu 2011). Non-western countries such as Japan and India, for example, prioritize work first and family second while some organizations rank country first followed by the organization and then the self. This priority ranking indicates that some employees are willing to sacrifice family for the sake of their work and career advancement (Chandra 2012). In the 2013 Malaysian Budget, there was a call for action to promote employees' work-life quality in the form of tax incentives for organizations to provide childcare facilities or allowances for employees ('Budget 2013: Tax breaks, affordable housing and cash for the needy', 2012). However, WLB practices in Malaysia are uncommon as a study has found that both Malaysian employers and employees generally do not value WLB and the interests of non-work are also seen as unimportant by employers (Au and Ahmed 2014). Hence, the Malaysians' expectations towards WLB practices may differ from those in western countries (Wong, Bandar and Saili 2017).

Past studies have examined several predictors of WLB at the individual level such as work-family conflict (Md-Sidin, Sambasivan and Ismail 2010), family support (Valcour et al. 2011), and supervisor support (Talukder, Vickers and Khan 2018). These studies focused more on proximal support and often neglected the importance of distal levels (Sánchez-Vidal, Cegarra-Leiva and Cegarra-Navarro 2012). While implementation of organizational practices at the organizational or distal level is equally as important as employees' perception of such practices at the individual or proximal level (McCarthy et al. 2013), the influence of organisational practices applied by managers on employees and their subsequent impact on employee behavior has not been fully examined. This study uses both distal and proximal supports of the supportiveness theory, ranging from the WLB practices support to employee perceptions of these practices in the workplace, using the sample of small and medium-sized enterprises (SMEs) in Malaysia. In general, SMEs are less structured and have a higher sense of ownership among employees than large firms because employees in SMEs typically have more freedom, more relaxed relationships, and more flexible communication channels with senior management (Carsrud and Brännback 2011). Therefore, any support practices or activities that managers provide to their employees are often in line with employee perceptions resulting from high-quality of manager-employee relationships.

The relational perspective suggests that quality manager-employee relationships can be developed when three conditions - such as mutuality, interdependence, and reciprocity - are fulfilled (Hall 1996). From the relational perspective, the implementation of human resource (HR) practices must be viewed as a pattern of relationship (Sun, Aryee and Law 2007) and in a consistent manner (Renwick 2003; Whitener 2001) that is conducive to shaping appropriate employee behavior. Therefore, the organisation's WLB practices should be viewed consistently by employees too. For instance, if employees find strong support that management cares about their well-being, similar support strengths should 
be seen in other practices that affect them. While HR practices have been associated with employee outcomes such as commitment, the literature regarding WLB practice has not been adequately explored, particularly in different levels such as distal and proximal levels that could influence employee well-being in a Malaysian context. To address this gap in research, the current study links WLB practices perceived by managers at the organizational level to employee commitment at the individual level using supportiveness and relational perspectives.

Research question: The primary research question of the current study is:

1. How are work-life balance practices linked to employee commitment?

Figure 1 shows the study's conceptual framework, examining the relationship between WLB practices at organizational level, employee-perceived WLB practices, performance appraisal, and their commitment at individual level.

\section{Theoretical background and hypotheses}

\section{Perception of WLB practices among manager and employee}

As WLB practices are gaining increasing attention in the literature (Coyle-Shapiro and Shore 2007), it is important to explore how these practices affect employee outcomes, particularly their behavior. WLB practices are usually defined as 'any employer-sponsored benefit or working condition that helps an employee to balance work and non-work demands' in literature (Cascio 2000, 166). Common WLB practices such as flexible work and time arrangements, work leaves, and employee assistance programs (Cascio 2000) are the few practices implemented by organizations. HR managers usually play an important role in implementing or assessing the effectiveness of HR practices offered by the organization (Den Hartog et al. 2013) and are also responsible in improving employee well-being (McCarthy et al. 2013). However, using a single source to evaluate the effectiveness of work-life balance activities as part of HR practices may be too simplistic as these activities involved the implementer (i.e. manager) and recipient (i.e. employees). Therefore,

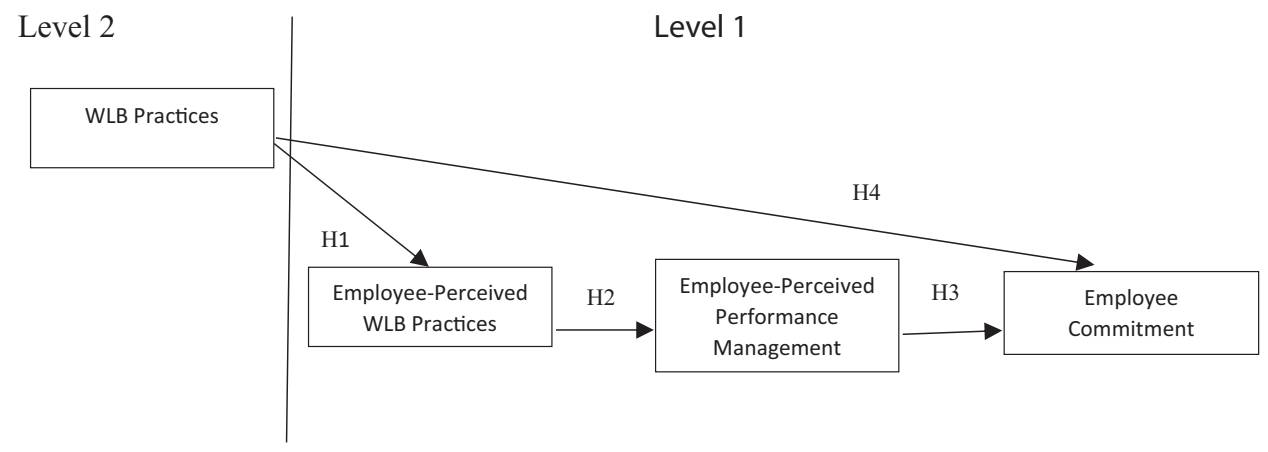

Figure 1 Conceptual framework. Note: WLB, work-life balance; H, hypothesis 
knowing what WLB practices implemented by managers is precisely with what employees perceive at the workplace is important to indicate the effectiveness of their implementation. In fact, the effectiveness of practices involving human resources implemented in organizations depends on both the organizational and individual levels (Den Hartog et al. 2013) as organizational support in WLB practices may contribute to employee uptake of such practices.

The current study concurs with McCarthy et al.'s (2013) argument that the outcome of providing work-life balance should not be examined only at the individual level as it is multifaceted. McCarthy et al.'s (2013) theory of supportiveness is the fundamental principle of social support theory and operates on two main levels: the proximal level of support where it is demonstrated by immediate supervisors while distal support is shown by organizations typically represented by formal policies and informal attitudes from HR managers. To date, the majority of proximal support measures have focused on supervisory support and its impact on employee outcomes but have rarely explored distal factors that affect employees at multilevel (McCarthy et. al. 2013). 'Proximal' in healthcare refers to something closer to the trunk, where it is nearer to the point of attachment. In other words, proximal support in the context of this study is WLB support that employees can feel, involve and experience closely. Unlike the study conducted by McCarthy and others in which they used supervisory support as a proximal study, this study expects the views, involvements and experiences of employees derived from the support provided by organizations at the individual level to have closer impact on their own commitment.

The definition of 'distal' in healthcare refers to the areas and places away from the trunk - McCarthy and others have defined distal support as the formal and informal support of the organization using HR managers. In general, HR managers are known as agents for initiating WLB practices as it is usually their department that implemented the WLB practices (Whitener 2001). In this case, the way HR managers demonstrate WLB practices formally at the distal level is expected to influence employees' perception of WLB practices at the proximal level. When organizations support all employee well-being initiatives, employees may respond positively to WLB practices (see Lapierre et al., 2008; Mas-Machuca, Berbegal-Mirabent and Alegre, 2016).

However, instead of using HR managers to represent the organizational level, this study used an immediate superior to represent the distal support. The small and intermittent actions by immediate superiors can influence employees' perceptions of the policies and practices implemented by organization. Manager support may bring a negative effect on employees which in turn influences employees to have negative perceptions such as low self-esteem and low quality of work life (Nahum-Shani, Henderson, Lim and Vinokur, 2014). To counter the negative impact, it is salient to ensure a high-quality relationship between supervisors and employees, as a close relationship can buffer the negative impact, and it can promote positive outcomes such as higher job satisfaction and career success (see Bolino and Turnley, 2009). The social support theory indicated that social relationships influence health and well-being (Lakey and Cohen, 2000). The current study expects a high-quality relationship between the immediate superior and employees in 
SMEs. A previous study confirmed that HR practices implemented in SMEs may foster supportiveness as they perceive a sense of ownership more than in large organizations (Galabova and McKie 2013). The sense of ownership among SME employees invites informal, open, developing and long-term interactions (Rousseau and McLean Parks 1993) that strengthen their relationship with managers. A superior's position of authority and their acts of support at distal level in relation to organization practices such as WLB, indicate to employees that their supervisor values them. Thus, th distal level of support in this study context refers to immediate superior perception on the WLB practices that are seen, available and implemented at the organizational level. The term 'managers' is used interchangeably in this study to represent immediate superiors. Hence, based on extant theory and research this study predicts that:

Hypothesis 1: Perceptions of WLB practices of managers and employees within SMEs are consistent, when managers' perceptions of WLB practices are positive, employees will perceive the WLB practice positively.

\section{The mechanism linking WLB practices and employee commitment}

Many studies have found HR practices in an organization impact employee outcomes (Renwick 2003; Whitener 2001). Organizational support such as WLB practices offered to employees is seen as beneficial when they perceive that the support is intended to improve their personal lives. WLB practices such as flexible work arrangements were found to provide various benefits to the organization such as improvement in employees' attitudes and behavior as well as firm performance (Beauregard and Henry 2009). Formal or informal support for WLB practices at the workplace are indicators to employees that their employers care about their well-being, which may generate positive feelings and increase their commitment to the organization. The responsibilities of HR managers include ensuring employees' well-being (Brown et al. 2009), thus any activities that relate to improving the well-being of employees is part of the HR practices. Employees' positive perception of work-life support is said to increase other employee outcomes such as job satisfaction, retention, performance, productivity, and so on (Allen 2001; Hughes and Bozionelos 2007).

WLB practices are important but they may be inadequate to address employee motivational levels such as organizational commitment. Explanations of the process of implementing HR practices have been overlooked in the literature (Woodrow and Guest 2014) and previous studies have largely ignored the importance of investigating the organization-employee relationship in relation to work-life balance (Nijp et al. 2012). Some studies found WLB practices to have a negative impact as work-life activities because they are perceived as increasing the worker's workload and affecting work coordination (Poelmans and Beham 2008). Furthermore, it is difficult for employees to generate positive feelings towards WLB practices when they are vague or unaware of such practices being offered in their organization. In fact, Prottas et al. (2007) found that employees have insufficient 
information about how WLB practices improve their well-being and some employees are suspicious of these practices (Budd and Mumford 2006).

The inconsistent findings from past studies imply the need for clear and consistent practices involving HR practices that are implemented within the organization. The consistency of practices implemented in the organization represents an important antecedent of employee commitment that may alter their perception on WLB practices. This study concurs that consistency of HR practices affects employee work-related outcomes based on the relational perspective (Renwick, 2003; Whitener 2001). When WLB practices implemented at organization level are viewed positively and applied consistently like other HR practices, employees would usually reciprocate positively in the form of commitment to the organization. HR practices are often seen as communication tools from the organization to employees (Guzzo and Noonan 1994) and employees view the availability of HR practices as organizational intention (Bal, Kooij and De Jong 2013). This is particularly so when employees perceive WLB practices to be consistent with how they are appraised in their performance.

Performance appraisal is the formal assessment of employee performance involving the objectives, activities, outputs, and targets of a job over a specified period (McNamara 1999). It is one of the most important components of HRM (Nankervis, Compton and Baird 2005) because effective performance appraisal creates a clear association effect between organizations and individuals (DeNisi and Sonesh 2010). According to Lakey and Cohen (2000), appraisals are defined as the way people interpret situations and can be divided into primary and secondary appraisals. Primary appraisal refers to the dimension at which a person includes judgement that they may receive threats or challenges during the appraisal process while secondary appraisals evaluate the likelihood of receiving personal and social resources during the event. Perceptions of social support received by individuals influence appraisal (Guay, Billette and Marchand 2006). Therefore, it is expected that perceptions of social support received, such as WLB practices, may be associated with perceptions of how their performance is appraised in the workplace. Previous researchers have confirmed that performance appraisal is one of the HR practices that when implemented effectively, can maintain a committed workforce (Boice and Kleiner 1997; Nasurdin, Hemdi and Lye 2008), provided that employees are perceived positively in their performance appraisal (Tziner and Murphyn 1999; Gupta and Kumar 2013).

As stated by Prottas et al. (2007), WLB practices will not benefit either organizations or employees if conflicting practice exists or they are unaware that such practice exists. An example of conflicting practice is organizations that claim to support employees by balancing work and family responsibilities, but they evaluate the employee's performance based on time spent at work. This contradictory practice clearly indicates that employees who spend more time at work will be appraised favorably, demonstrating inconsistency in practice that does not conform to WLB practices at their workplace. Consistent and supportive HR practices should be applied in organizations to generate greater human capital (Takeuchi et al. 2007) and it is particularly helpful when organization-employee goals are well aligned (Lepak and Shaw 2008). A consistent system refers to a situation where 
employees perceive that WLB practices they have received are unswervingly associated with actions from their immediate superiors where the employee performance is not only assessed for job improvement but is accounted for the well-being of the employees. The consistency of relationship between perceived WLB practices and perceived performance appraisal within the organization promotes productive attitudes among employees and increases their commitment towards the organization. The current study expects employee-perceived performance appraisal to mediate the relationship between employee-perceived WLB practices and employee commitment. Employees who perceive high WLB practices are likely to have a higher level of employee commitment based on how they perceive their performance is appraised in the workplace. This study hypothesizes that:

Hypothesis 2: Employee-perceived WLB practices will be positively related to their perceived performance appraisal at the individual level in SMEs.

Hypothesis 3: Employee-perceived performance appraisal will be positively related to their commitment at the individual level in SMEs.

By integrating distal and proximal supportiveness and relational perspective, the current study proposes that WLB practices perceived by managers who represent the organizational level (i.e. distal level) affect employees' perception of WLB practices at the individual level. This is followed by a consistent perception of performance appraisal (i.e. proximal level), which in turn affects employee attitudes. From a relational perspective, when employees perceive HR practices as mutually beneficial and consistently applied across the organization, employees may develop a positive attitude towards their work. The degree to which employees perceive HR practices in the context of their work determines their response to the HR systems (Bowen and Ostroff 2004). Consistent HR practices are claimed to produce better employee performance than individual HR practices (Delery and Shaw 2001). There may be a relational effect between the two HR practices when both practices share the same objective (cf. Kirkpatrick 2012), in particular, assuming that perceived WLB practices and perceived performance appraisal may have the similar objective of improving employee commitment. The WLB practices that managers perceive to be implemented within the organization at a distal level are simply insufficient if they are not integrated with the proximal environment of HR practices that are perceived consistent. The availability of two levels of support, distal and proximal, is more evident in SMEs as these organizations emphasize informal and less-structured relationships in which their high-quality manager-employee relationships are expected to promote employee commitment. This study addresses the gap by conducting multilevel understanding that aims to provide a link between the WLB practices perceived by managers at the distal level with the proximal level of employees.

Hypothesis 4: The positive relationship between WLB practices at the organizational level and employee commitment will be mediated by employee-perceived availability of WLB practices and performance appraisal at the individual level in SMEs. 


\section{Method}

\section{Participants and procedures}

Small and medium-sized enterprises (SMEs) of various industries in Malaysia participated in this study. Recruiting participants from different industries prevents any limitation on contextual aspects that accompany certain organizations (Johns 2001). SMEs were chosen because they are expected to foster a quality relationship that can minimize the gap between organization and employee with regard to practices, because of a sense of ownership among SMEs employees (Galabova and McKie 2013). Furthermore, SMEs are always an important economic agent for Malaysia as it strives for $62 \%$ employment for the nation (SME Corporation Malaysia 2015). A total of 74 SMEs in Malaysia agreed to participate, of which $46.7 \%$ of them are service enterprises, $34.2 \%$ are in manufacturing-related services, and $19.1 \%$ are in the manufacturing industry (including agro-based enterprises). One manager from each of the 74 SMEs was recruited to represent the organizational level perspective on WLB. Therefore, a total of 74 managers from various SME industries participated in this study. Face-to-face interviews, follow-up calls and e-mail communications were conducted in each firm to explain the data collection procedure and to persuade them to participate. To assess WLB on the individual level, 319 employees from these 74 SMEs were recruited randomly and were required to provide data regarding their age, gender, education level, salary, perceived WLB practices, perceived performance appraisal, and commitment towards their organization. A representative from each firm was responsible for distributing and collecting questionnaires from employees. The employees completed the questionnaires during breaks at work or at home and returned them in a sealed envelope to the representative in each firm. The author collected the completed surveys from the representatives. Of the 319 employees, $51.7 \%$ of them were male and the average age of employees was 32 years. The employees' average salary was RM 3000. In terms of education level, 58.9\% of employees had a diploma-level qualification or lower, $39.5 \%$ had a bachelor's degree, $1.3 \%$ had a master's degree, and $0.3 \%$ did not enter their educational level. The number of employees for each of the 74 SMEs varied from 1 to 8 employees $($ mean $=4.31)$.

\section{Instruments}

WLB practices and performance appraisal constructs were measured using scales developed by the author for this study. Based upon Guest, Conway and Dewe's (2004) sequential tree analysis of HR practices, six items were written to describe work-life balance practices and five items describe performance appraisal practices. Respondents rated each practice using a 6-point Likert scale ranging from 1 (strongly disagree) to 6 (strongly agree). Factor analysis (principal component: oblique rotation) revealed three factors. Two factors emerged that reflect the human resource practices. The first factor explained $26.6 \%$ of the variance. A scale named performance appraisal was created by summing across five items that defined this factor. The second factor explained $11.1 \%$ of the variance. A scale named WLB practices was created by summing across six items defining this second 
factor. WLB practices were used on both managers and employees; however, the way they were asked to answer the instrument was different. Managers were asked to indicate how much they agree with current WLB practices in their organization. An example item is: 'We support employees with balancing work and family responsibilities'. Employees were asked to indicate how much they agree that WLB practices have been implemented in their organization. An example item is: 'My manager supports employees with balancing work and family responsibilities'. The reliability coefficients of this instrument for managers and employees were 0.744 and 0.625 respectively. An example item of performance appraisal practice is: 'Pay raises and promotions are closely tied to my performance outcomes'. The reliability coefficient of this instrument for employees was 0.685 .

Employee commitment was assessed using six items (current study $\alpha=0.787$ ) rated on a 6-point scale from Allen and Meyer's (1990) organization commitment scale. Only six items from this scale that targets positive feelings were selected as the objective of this study is to explore if HR practices are the driver of employee overall commitment. The items selected were: 1) happy to spend the rest of career; 2) organization's problems are my own; 3) staying is a matter of necessity as much as desire; 4) another organization may not match the overall benefits I have here; 5) deserves my loyalty; and 6) move from company to company too often.

\section{Control variables}

The control variables in the current study are demographic variables measured as nominal variables. These include age (four categories), gender (coded as male $=1$ and female $=2$ ), education level (four categories), and salary (six categories). These variables were measured at the individual level to reduce the possibility of spurious results. At the organizational level, the SMEs' industry type (also a control variable) was coded as three categories ( manufacturing $=1$, manufacturing-related services $=2$, and services $=3$ ). Descriptive statistics related to the variables are shown in Table 1.

\section{Results}

Data in this study were collected from the same source (i.e. the employee), thus making the results of this study vulnerable to common method bias. To minimize concerns pertaining to this issue, participants were assured of anonymity and confidentiality of their responses. In addition, this study used the statistical remedies to ensure that common method bias is not a problem in this study. The results from Harman's ex post one-factor test showed that the first factor accounted for only $14.16 \%$ of the total $55.11 \%$ variance, indicating that a single factor does not explain the majority of the variance (Podsakoff et al. 2003). The variance inflation factors (VIFs) were calculated and all VIF values of this study are below three, indicating that multicollinearity is not a serious problem in this study (Hair et al. 2012). The measurement model of this study was tested for the four selfreported variables to assess the validity of the construct. Four constructs (WLB implemented, perceived WLB, perceived performance appraisal and employee commitment) 
Table 1 Means, standard deviation, reliability, and Pearson's bivariate correlations

\begin{tabular}{|c|c|c|c|c|c|c|c|c|c|}
\hline Variables & Mean & $\mathrm{SD}$ & 1 & 2 & 3 & 4 & 5 & 6 & 7 \\
\hline \multicolumn{10}{|l|}{ Individual level } \\
\hline 1. Age & 1.44 & .73 & - & & & & & & \\
\hline 2. Gender & 1.48 & .50 & .01 & - & & & & & \\
\hline 3. Education level & 1.42 & .52 & -.10 & .06 & - & & & & \\
\hline 4. Salary & 2.84 & 1.03 & $.331^{\star *}$ & .02 & $.399^{* *}$ & - & & & \\
\hline 5. WLB practices & 4.04 & .67 & .03 & .05 & .10 & .05 & $(.62)$ & & \\
\hline $\begin{array}{l}\text { 6. Performance } \\
\text { appraisal }\end{array}$ & 3.89 & .71 & $-.140^{\star}$ & .07 & .01 & -.05 & $.609^{* *}$ & $(.68)$ & \\
\hline $\begin{array}{l}\text { 7. Employee } \\
\text { commitment }\end{array}$ & 3.59 & .86 & .07 & .03 & -.03 & .03 & $.286^{\star *}$ & $.243^{\star *}$ & $(.74)$ \\
\hline \multicolumn{10}{|l|}{ Organizational level } \\
\hline 1. Sector type & 2.27 & .79 & - & & & & & & \\
\hline 2. WLB practices & 4.31 & .74 & .037 & $(.69)$ & & & & & \\
\hline
\end{tabular}

Number of employees $(N)=319$; number of SMEs $(n)=74$. Coefficient $\alpha$ is provided along the diagonal line. Age coded in 4 categories; gender coded as male $=1$ and female $=2$; education level coded in 4 categories; salary coded as in 6 categories; and sector type coded in 3 categories.

${ }^{*} p<0.05,{ }^{* *} p<0.01$.

were measured where the fit among a series of confirmatory factor analysis models was compared to determining the best-fit model. The fit of the models was measured using the procedures used by Koon and Chong (2018). The hypothesized four-factor model exhibited the best fit $\left(\chi^{2} \quad(113)=149.43, \quad p<0.01 ; \quad\right.$ CFI $=0.95 ; \quad$ TLI $=0.94$; RMSEA $=0.032)$. The three alternative models yielded poor fit to the data: $\chi^{2}$ $(116)=300.36, p<0.01 ; \mathrm{CFI}=0.76$; TLI $=0.72$; RMSEA $=0.07$ (three-factor model), $\chi^{2}(118)=380.78, p<0.01 ;$ CFI $=0.66$; TLI $=0.60$; RMSEA $=0.08$ (two-factor model), and $\chi^{2}(119)=591.74, p<0.01$; CFI $=0.38$; TLI $=0.29$; RMSEA $=0.11$ (one-factor model). Thus, the constructs of hypothesized models achieved the discriminant validity.

Data analyses on all proposed models based on maximum likelihood estimation were performed using SPSS MIXED procedure for multilevel regression models. Only the proposed model intercepts were allowed to vary as random effects at the individual level while all predictor variables were considered as fixed effects. The fixed effects were WLB practices implemented at the organization level (level-2 variable) on employees' perception of WLB practices and performance appraisal towards employee commitment (level-1 variables).

The variables' mean, standard deviation, reliability, and correlation values are presented in Table 1 . The reliability for the variables ranged from 0.62 to 0.74 at the individual level, indicating an acceptable scale of reliability for each instrument used. In terms of the perceived availability of WLB practices in the workplace, managers reported a higher level of agreement $(M=4.34, \mathrm{SD}=0.74)$ than employees $(M=4.04, \mathrm{SD}=0.67)$. 
Employees reported a lower level of agreement regarding performance appraisal $(M=3.89, \mathrm{SD}=0.71)$ and employee commitment $(M=3.59, \mathrm{SD}=0.86)$ as compared to their ratings on WLB practices.

As an initial step, the current study assessed null models which contain a random effect model that has no level-1 or level-2 variables. The percentages shown in Tables 2 and 3 confirmed that the between-organization variance is sufficient to justify the examination of between-employee predictors of the dependent variable employee commitment (35\%, Wald $Z=4.105, p<0.001$ ), and the lower level mediator performance appraisal (34\%, Wald $Z=3.995, p<0.001)$ and WLB (32\%, Wald $Z=3.919, p<0.001)$. These significant results indicate possible cross-level influences of WLB practices and employeeperceived WLB practices and performance appraisal.

The current study hypothesized that organization-implemented WLB practices are positively related to employee-perceived WLB practices. However, the results failed to support the hypothesis (Model 3; $\gamma_{01}=0.05, \mathrm{~ns}$ ) and therefore Hypothesis 1 was rejected.

Employee-perceived WLB practice is positively related to employee-perceived performance appraisal $\left(\gamma_{20}=0.63, p<0.001\right)$ that shows a relational relationship supporting Hypothesis 2. This suggests that an addition of a within-group predictor, particularly employee-perceived WLB practices, reduces residual (within-group) variability (i.e. from 0.309 in the null model to 0.237 in the Level 1 model). Hence, employee-perceived WLB practices account for about $19 \%$ of the within-organization variability in employee-perceived performance appraisal. The introduction of employee-perceived WLB practices into the model provided a significant explanation that variability exists at the within-organization level (Wald $Z=11.046, p<0.001$ ) and between-organization level (Wald $Z=3.412, p<0.01)$.

The results also supported Hypothesis 3 as employee-perceived performance appraisal was found to be positively related to employee commitment (Model 1a; $\gamma_{10}=0.28$, $p<0.0001)$. When employee-perceived performance appraisal was added to the null model, residual (within-group) variability was reduced (i.e. from 0.332 in the null model to 0.479 in the Level 1 model). This suggests that employee-perceived performance appraisal accounts for about $44 \%$ of the within-organization variability in employee commitment. The introduction of employee-perceived performance appraisal into the model provided a significant explanation about variability at both within-organization level (Wald $Z=11.160, p<0.001$ ) and between-organization level (Wald $Z=4.105$, $p<0.001)$.

The current study found a primary cross-level main effect of WLB practices on employee commitment (Model 1d; $\gamma 01=-0.18$, SE $=0.09, p<0.05$ ) but it was a negative relationship instead of the expected positive relationship. This study uses the MLmed macro by Rockwood and Hayes (2017) to measure multilevel mediation analysis, following the approach outlined in Preacher, Zyphur and Zhang (2010) to reduce the possible limitations of the analysis. Both within- and between-person effects of the model were estimated in one model, and Monte Carlo estimation was used to estimate indirect effects. All random intercepts were included in the model. All parameters were assessed using a 2- 


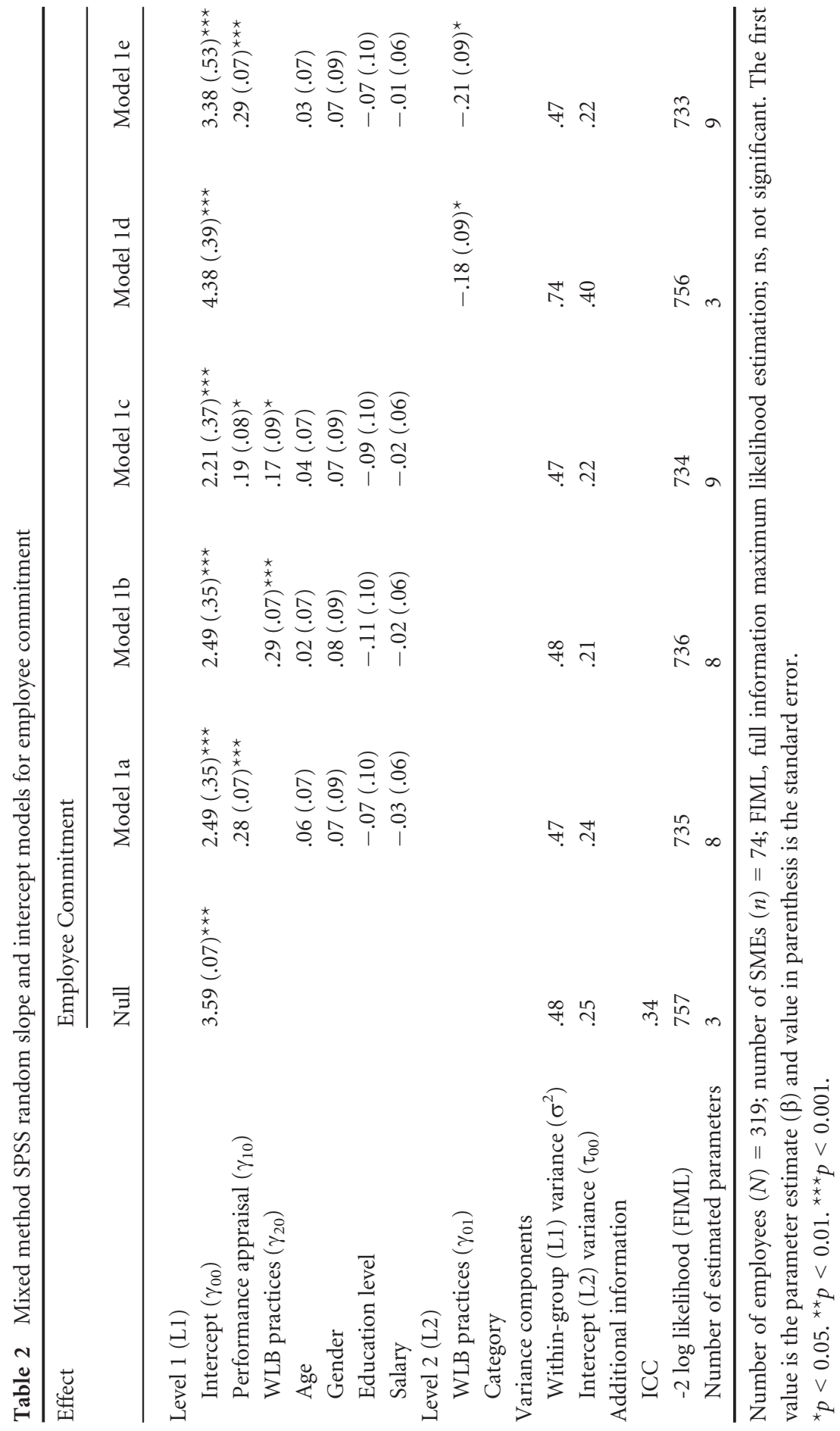




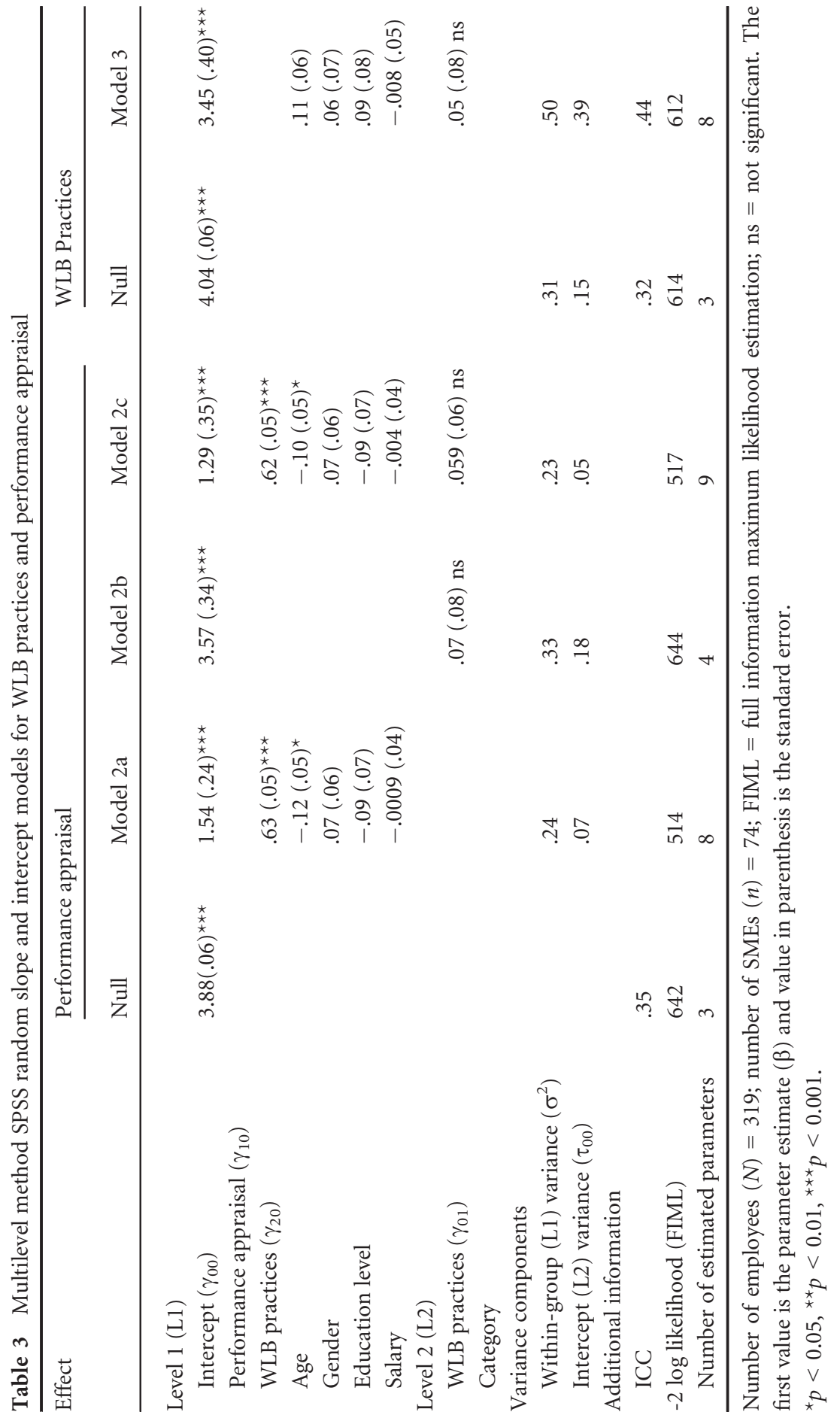


1-1 mediational model. As there is no within-group effect for level-2 variables (organization-level), only between-group effects were measured. Control variables between random intercepts and effects were not included in the 2-1-1 mediational model. The prediction that employee-perceived WLB practices serve as mediator was not supported as the results were not statistically significant. Employee-perceived performance appraisal was also examined as a possible parallel mediator but the results showed similar statistically nonsignificant indirect effects. These results indicate that both variables have no mediating effect on the relationship between manager-implemented WLB practices and employee commitment and, hence, Hypothesis 4 was not supported.

Based on the descriptive statistics presented in Table 1, managers have indicated a higher level of agreement of WLB practice while employees' perception of WLB practices is scored significantly lower. Ad hoc analysis was conducted in which a paired sample $t$ test was used to calculate any possible differences. The result was statistically significant $(t=-4.916, p<0.001)$ indicating that score differences exist between managers and employees in SMEs. In addition, perceptions between manager and employee in terms of WLB practices were examined to identify congruence effect. Prior to the analysis of polynomial regression, Shanock et al. (2010) recommended to examine the occurrence of support discrepancies in which the scores of the two predictor variables (i.e. manager- and employee-perceived WLB practices) were standardized. Any participant with a standardized score on one predictor variable that is half the standard deviation above or below the standardized score on the other predictor variable is considered to have discrepant values. As shown in Table 4, the result indicates that the values of both predictors achieved agreement for $68.03 \%$, while the total occurrence of discrepancies between employee-perceived WLB practices and manager-perceived WLB practices is only $31.9 \%$. Since there is only $31.9 \%$ of the predictor variables that show discrepant values, polynomial regression was not performed in this study.

\section{Discussion}

The key findings of the current study are threefold in answering the research question on how WLB practices are linked to employee commitment. It was hypothesized that supportiveness of the manager at the distal level on WLB practices is seen as an investment to employees and will generate positive outcomes such as employee commitment. However,

Table 4 Agreement between employee- and manager-perceived WLB practices

\begin{tabular}{lccc}
\hline Agreement groups & Percentage & Mean $(\mathrm{E})$ & Mean $(\mathrm{M})$ \\
\hline E more than M & 16.6 & 4.80 & 3.31 \\
In agreement & 68.03 & 4.00 & 4.39 \\
E less than M & 15.3 & 3.37 & 4.91 \\
\hline
\end{tabular}

$N=319 ; E=$ employee-perceived WLB practices, $\mathrm{M}=$ manager-perceived WLB practices. 
contrary to the hypothesis and findings from past research, the results surprisingly found a negative relationship between WLB practices at the distal level and employee commitment. The results suggest that employee outcomes are not always positive if this relationship is examined using a multilevel approach.

The study also explored the idea of association between manager-implemented WLB practices at the organization level and employee-perceived WLB practices at the individual level. However, the relationship between the two variables was not statistically significant, indicating that both of them within SMEs may not necessarily be related to each other even though the organization-employee relationship is closer to that of the larger firm. Analysis using $t$-tests revealed that there was a significant difference in response to WLB practices between managers and employees. Managers on average may believe that WLB practices in the organization have been successfully implemented, but on average employees may believe otherwise. This finding is consistent with the other researchers (e.g. Kuvaas 2008) that a gap exists between manager-implemented and employee-perceived organization practices regardless of firm size or relationship quality. However, the level of agreement of each standardized score between managers- and employees-perceived WLB practices examined indicated an interesting finding. The majority of the predictor value agree on the availability of the WLB practices in their workplace. Samples collected from SMEs do not offer significant differences from one direction or another. Although polynomial regression was not practical to perform in this study to test the effect of congruence or incongruence, this high level of agreement signifies that organizational perceptions in one participant do not influence other participants (i.e. employees). In social psychology literature, conformity in perception was found to increase only when individuals with disagreement in social entities increased (Wilder 1977). Minimal disagreements between managers and employees of SMEs due to harmonious relations increase the likelihood of WLB practices agreement. By having conformity, individuals will have less effort to influence others especially in discussing their perceptions with others. Therefore, this may be the reason why there is no significant relationship between manager- and employee-perceived WLB practice despite strong agreement of WLB availability in their organization.

While not all of the hypotheses were supported, this study has substantial implications. This study answered the call for research to investigate the perceptions of both managers and employees with regard to HR practices (Nishii et al. 2008). Focusing entirely on employees' perceptions towards HR practices and how they lead to employee behaviors may lead to an overestimation of the relationship due to single-source bias (Den Hartog et al. 2013). Results found that manager-perceived WLB practices and employee-perceived WLB practices both affect the employee commitment significantly. It is worth noting that perceptions of WLB practices irrespective of the level of support influence employee attitudes and this confirms the importance of understanding the function of distal and proximal theory of supportiveness, highlighting the need to use multiple sources in studying organizational and employee outcomes.

On a separate note, employee-perceived performance appraisal was found to have a mediating effect on the relationship between employee-perceived WLB practices and 
employee commitment at the individual level, although this is not within the hypotheses posited. The results, although not reported in the results section, showed there was a main effect between employee-perceived WLB practices and performance appraisal $(\gamma 20=0.63, p<0.001)$, the relationship between employee-perceived performance appraisal and employee commitment in the model was also statistically significant (Model 1a; $\gamma 10=0.28, p<0.001)$. The direct relationship between employee-perceived WLB practices and employee commitment (Model 1b; $\gamma 20=0.29, p<0.001$ ) was reduced after employee-perceived performance appraisal was added into the relationship (Model 1c; $\gamma 20=0.17, p<0.05)$. These results indicate a mediation effect has occurred between employee-perceived WLB practices and employee commitment via employee-perceived performance appraisal $(95 \%$ CI, lower level $=0.0305$, upper level $=0.236)$. This finding supports the belief that from a relational perspective, HR practices perceived as in line with the organization's performance appraisal by employees will result in positive employee outcomes. Therefore, managers should implement a consistent HR system that supports employee well-being in a way that improves employees' work performance and is aligned with performance evaluation criteria set by the organization.

The current study was conducted in Malaysia and has resulted in findings that contradict past research. This implies that past research on WLB that was mostly done in a western context may not be generalizable to non-western countries, a belief supported by Shaffer et al. (2011). For instance, Hassan (2010) suggested that different cultural aspects should be taken into consideration when implementing WLB practices in Malaysia. Organizations in Malaysia tend to prioritize work over non-work interests, creating a culture and climate among employees to underestimate their non-work interests for their work performance. As a result, WLB practices implemented by managers can be seen as another gimmick used to improve employee work performance even though sense of ownership among employees in SMEs is higher than that of larger firms. It is important to reduce this disparity of perception between managers and employees so that the practices implemented by managers are viewed positively by employees. In reference to the ad-hoc analysis conducted, this study implies that manager and employee may share the similar level of agreement on WLB practices but that does not mean that their perceptions of the availability of these practices affect each another especially in the SME environment. SMEs should not confine their employees to the conformity stage where they need to accept organizational practices as given. Organizations must learn how to solicit input and communicate effectively so that employees and managers have clear perceptions that influence one another for their desired employee behavior.

Instead of using HR managers and immediate superiors as two levels of supports (see McCarthy et al. 2013), this study measures the perception of the immediate superior as distal support and employee themselves as proximal support. Most researchers typically examined WLB in large organizations but not so much in SMEs. Many SMEs have no specific department to handle HR matters (Messersmith and Guthrie 2010) and this lack of professional and formal HR practices in organization may lead to poor perception of such practices among employees. Therefore, collecting feedback from an HR manager to 
measure on SMEs does not make practical sense. On the other hand, employee perceptions are the best indicator of the proximal level as it is the closest support received by employees. When employees perceive the availability of WLB practices in their organization, employees generally act on their perceptions rather than objective reality (Katz and Kahn 1978) and thus they indicate that perception is the truth in people's minds. Subsequently, the study's finding confirms that without the relational perspective of distal level (i.e. organization level) with proximal level (i.e. individual level), there will be less desired organizational and employee outcomes (i.e. employee commitment). Positive outcomes will be achieved with the consistency of proximal support as well as the interaction of managers at the distal level. The managers who implement these practices should be seen as willing, understanding and supportive towards the employees' well-being.

\section{Limitations and future research}

The current study has several limitations. Firstly, data was collected based on a cross-sectional approach which does not prove causality and is unable to fully capture the dynamic nature of the relationship between WLB practices and employee commitment. To rectify this problem, this study has used multiple cross-sectional designs where data from two different types of respondents (i.e. managers and employees) were collected at a given time. Comparison between data on the aggregate level was then made against the individual level. In addition, this study used a moderate-sized sample. Nonetheless, future research should examine for causality via longitudinal studies and validate current results using a larger sample.

Based on a theory of supportiveness, this study argues that the influence of WLB practices at the organizational level on employee commitment at the individual level is mediated by employee-perceived WLB practices and performance appraisal in SMEs firm. However, no mediation effect was found but a significant difference in perception of WLB practices was found between managers at the organizational level and employees at the individual level. Respondents in the current study are employees from Malaysian SMEs. While previous researchers have confirmed that employees working in SMEs tend to have a better sense of ownership and higher quality of organization-employee relation, these features may not be as common in the Asian context. A survey conducted by PwC (Malaysia) 2018 found $69 \%$ of fraud cases in Malaysia over the last two years were committed by internal staff who were senior management (Wong 2018). This statistic is alarming as employees may lose trust in the people they work with, or the people they work for. This creates a work environment that could enlarge the gap between what organization is implementing and what the employees perceive. Future studies may replicate this study to SMEs in countries with a high trustworthy index as researchers find that employees will trust managers when managers in the workplace fulfil their promises sincerely and deal with employees honestly (Nichols et al. 2009) and this 'trust' construct may influence perceptions. 
In addition, the majority of the sample data shows a high level of agreement between manager- and employee-perceived of WLB practices that may be due to high conformity in SMEs with less opposition. Thus, future studies can replicate this study by using large firm size when the number of employees is larger, and disagreement or opposition among employees can reduce the likelihood of conformity that intensify each other's perception. The congruence and incongruence effect for different perceptions, particularly at various levels of the large firm in relation to employee outcomes, can be examined using polynomial regression with response surface analysis. This analysis addresses the limitation of perception differences between respondents that allows us to explore how these discrepancies affect an outcome variable.

Control variables between random intercepts and effects were not included when the multilevel mediation modelling was tested. This is because the MLmed macro can only accommodate up to three level-1 covariates while this study has proposed four covariates - age, gender, education level and salary. Separate studies were conducted to include three randomized covariates in the analysis which found that the inclusion of the control variables did not deviate from the findings. Future research could use multilevel structural equation modelling to better understand any possible effects of unobserved heterogeneity at the different levels.

Dr Vui-Yee Koon is a Senior Lecturer in the Department of Management at the Sunway University, where she has been since 2014. Her research interests span both strategic human resource management, industrial organizational (IO) psychology and humanistic management. Much of her work has been on improving the employee performance regarding attitudes and behaviors.Uncited references

\section{References}

Allen TD (2001) Family-supportive work environments: the role of organizational perceptions. Journal of Vocational Behavior 58(3), 414-435.

Allen NJ and JP Meyer (1990) The measurement and antecedents of affective, continuance and normative commitment to the organization. Journal of Occupational Psychology 63(1), 1-18.

$\mathrm{Au}$ WC and PK Ahmed (2014) Sustainable people management through work-life balance: a study of the Malaysian Chinese context. Asia-Pacific Journal of Business Administration 6(3), 262-280.

Bal PM, DT Kooij, and SB De Jong (2013) How do developmental and accommodative HRM enhance employee engagement and commitment? The role of psychological contract and SOC strategies. Journal of Management Studies 50(4), 545-572.

Beauregard TA and LC Henry (2009) Making the link between work-life balance practices and organizational performance. Human Resource Management Review 19(1), 9-22.

Boice DF and BH Kleiner (1997) Designing effective performance appraisal systems. Work study. 46 (6), 197-201.

Bolino MC and WH Turnley (2009) Relative deprivation among employees in lower-quality leadermember exchange relationships. The Leadership Quarterly 20(3), 276-286. 
Bowen DE and C Ostroff (2004) Understanding HRM-firm performance linkages: the role of the 'strength' of the HRM system. Academy of Management Review 29, 203-221.

Brown M, I Metz, C Cregan and CT Kulik (2009) Irreconcilable differences? Strategic human resource management and employee well-being. Asia Pacific Journal of Human Resources 47(3), 270-294.

Budd JW and KA Mumford (2006) Family-friendly work practices in Britain: availability and perceived accessibility. Human Resource Management 45(1), 23-42.

Budget 2013: Tax breaks, affordable housing and cash for the needy. (2012). The Star.

Carsrud A and M Brännback (2011) Entrepreneurial motivations: What do we still need to know? Journal of Small Business Management 49(1), 9-26.

Cascio WF (2000) Managing a virtual workplace. Academy of Management Perspectives 14(3), 8190.

Chandra V (2012) Work-life balance: eastern and western perspectives. International Journal of Human Resource Management 23(5), 1040-1056.

Coyle-Shapiro JA and LM Shore (2007) The employee-organization relationship: Where do we go from here? Human Resource Management Review 17(2), 166-179.

Delery JE and JD Shaw (2001) The strategic management of people in work organizations: review, synthesis, and extension. In Research in personnel and human resources management, 165-197. Emerald Group, Bingley.

Den Hartog DN, C Boon, RM Verburg and MA Croon (2013) HRM, communication, satisfaction, and perceived performance: a cross-level test. Journal of Management 39(6), 1637-1665.

DeNisi AS and S Sonesh (2010) The appraisal and management of performance at work. In S Zedeck (ed.) APA handbook of industrial and organizational psychology: Selecting and developing members for the organization, Vol. 2: 255-279. American Psychological Association, Washington, DC.

Eby LT, WJ Casper, A Lockwood, C Bordeaux and A Brinley (2005) Work and family research in IO/OB: content analysis and review of the literature (1980-2002). Journal of Vocational Behavior 66(1), 124-197.

Galabova L and LJPR McKie (2013) 'The five fingers of my hand': human capital and well-being in SMEs. Personnel Review 42(6), 662-683.

Guay S, V Billette and A Marchand (2006) Exploring the links between posttraumatic stress disorder and social support: Processes and potential research avenues. Journal of Traumatic Stress: Official Publication of The International Society for Traumatic Stress Studies 19(3), 327-338.

Guest D, N Conway and P Dewe (2004) Using sequential tree analysis to search for 'bundles' of HR practices. Human Resource Management Journal 14(1), 79-96.

Gupta V and S Kumar (2013) Impact of performance appraisal justice on employee engagement: a study of Indian professionals. Employee Relations. 35(1), 61-78.

Guzzo RA, and KA Noonan (1994) Human resource practices as communications and the psychological contract. Human Resource Management 33(3), 447-462.

Hair JF, M Sarstedt, CM Ringle and JA Mena (2012) An assessment of the use of partial least squares structural equation modeling in marketing research. Journal of the Academy of Marketing Science 40(3), 414-433.

Hall DT (1996). Introduction: Long Live the career-A relational approach. In DT Hall \& associates (eds) The career is dead--long live the career. A relational approach to careers, 1-12. Josssey-Bass, San Francisco, CA. 
Hassan A (2010) Linking quality assurance to human resource management: a study of SMEs in Malaysia. International Journal of Quality and Reliability Management 27(6), 641-657.

Hughes J and N Bozionelos (2007) Work-life balance as source of job dissatisfaction and withdrawal attitudes: an exploratory study on the views of male workers. Personnel Review 36(1), $145-154$.

Johns G (2001) In praise of context. Journal of Organizational Behavior 22(1), 31-42.

Katz D and RL Kahn (1978) The social psychology of organizations, Vol. 2, 528). Wiley, New York.

Kirkpatrick DL (2012) Integrating training and performance appraisal. Training 49(4), 12-13.

Koon VY and KN Chong (2018) Workplace flexibility and organisational citizenship behaviour: an investigation of the mediating role of engagement and moderating role of perceived fairness. International Journal of Work Organisation and Emotion 9(1), 45-62.

Kuvaas BJJ (2008) An exploration of how the employee-organization relationship affects the linkage between perception of developmental human resource practices and employee outcomes. Journal of Management Studies 45(1), 1-25.

Lakey B and S Cohen (2000) Social support and theory. In Cohen S, Underwood LG and Gottlieb BH (eds) Social support measurement and intervention: a guide for health and social scientists, 2952. Oxford University Press, New York, NY.

Lapierre LM, PE Spector, TD Allen, S Poelmans, CL Cooper, MP O’Driscoll, Sanchez JI, Brough P and U Kinnunen (2008) Family-supportive organization perceptions, multiple dimensions of work-family conflict, and employee satisfaction: A test of model across five samples. Journal of Vocational Behavior 73(1), 92-106.

Lepak DP and JD Shaw (2008) Strategic HRM in North America: looking to the future. International Journal of Human Resource Management 19(8), 1486-1499.

Mas-Machuca M, J Berbegal-Mirabent and I Alegre (2016) Work-life balance and its relationship with organizational pride and job satisfaction. Journal of Managerial Psychology. 31(2), 586-602.

McCarthy A, JN Cleveland, S Hunter, C Darcy and G Grady (2013) Employee work-life balance outcomes in Ireland: a multilevel investigation of supervisory support and perceived organizational support. International Journal of Human Resource Management 24(6), 1257-1276.

McDonald P, K Brown and L Bradley (2005) Explanations for the provision-utilisation gap in work-life policy. Women in Management Review 20(1), 37-55.

McNamara C (1999) Basics of conducting performance appraisals. In J Dyro (eds) Clinical Engineering Handbook, 218. Elsevier Inc., Burlington MA.

Md-Sidin S, M Sambasivan and I Ismail (2010) Relationship between work-family conflict and quality of life: an investigation into the role of social support. Journal of Managerial Psychology 25(1), 58-81.

Mescher S, Y Benschop and H Doorewaard (2010) Representations of work-life balance support. Human Relations 63(1), 21-39.

Messersmith JG and JP Guthrie (2010) High performance work systems in emergent organizations: implications for firm performance. Human Resource Management 49(2), 241-264.

Nahum-Shani I, MM Henderson, S Lim and AD Vinokur (2014) Supervisor support: Does supervisor support buffer or exacerbate the adverse effects of supervisor undermining? Journal of Applied Psychology 99(3), 484-503.

Nankervis A, R Compton and M Baird (2005) Human resource management: strategy and processes. Nelson Australia Pty Limited, Southbank, Vic. 
Nasurdin AM, MA Hemdi and LP Guat (2008) Does perceived organizational support mediate the relationship between human resource management practices and organizational commitment? Asian Academy of Management Journal of Accounting and Finance 13(1), 15-36.

Nichols T, A Danford and AC Tasiran (2009) Trust, employer exposure and the employment relation. Economic and Industrial Democracy 30(2), 241-265.

Nijp HH, DG Beckers, SA Geurts, P Tucker and MA Kompier (2012) Systematic review on the association between employee worktime control and work-non-work balance, health and well-being, and job-related outcomes. Scandinavian Journal of Work, Environment \& Health 38(4), 299-313.

Nishii LH, DP Lepak and B Schneider (2008) Employee attributions of the 'why' of HR practices: their effects on employee attitudes and behaviors, and customer satisfaction. Personnel Psychology $61,503-545$.

Podsakoff PM, SB MacKenzie, J-Y Lee and NP Podsakoff (2003) Common method biases in behavioral research: a critical review of the literature and recommended remedies. Journal of Applied Psychology 88(5), 879-903.

Poelmans S and B Beham (2008) The moment of truth: conceptualizing managerial work-life policy allowance decisions. Journal of Occupational and Organizational Psychology 81(3), 393-410.

Preacher KJ, MJ Zyphur and Z Zhang (2010) A general multilevel SEM framework for assessing multilevel mediation. Psychological Methods 15, 209-233.

Prottas DJ, CA Thompson, RE Kopelman and EW Jahn (2007) Work-family programs: factors affecting employee knowledge and accuracy. Personnel Review 36(2), 163-189.

Renwick D (2003) Line manager involvement in HRM: an inside view. Employee Relations 25(3), 262-280.

Rockwood NJ and AF Hayes(2017, May). MLmed: An SPSS macro for multilevel mediation and conditional process analysis. Paper presented at the Poster presented at the annual meeting of the Association of Psychological Science (APS), Boston, MA.

Rousseau DM and J McLean Parks (1993) The contracts of individuals and organizations. Research in organizational behavior $15,1-43$.

Sánchez-Vidal ME, D Cegarra-Leiva and JG Cegarra-Navarro (2012) Gaps between managers' and employees' perceptions of work-life balance. International Journal of Human Resource Management 23(4), 645-661.

Shaffer MA, JR Joplin and Y-S Hsu (2011) Expanding the boundaries of work-family research: a review and agenda for future research. International Journal of Cross Cultural Management 11 (2), 221-268.

Shanock LR, BE Baran, WA Gentry, SC Pattison and ED Heggestad (2010) Polynomial regression with response surface analysis: A powerful approach for examining moderation and overcoming limitations of difference scores. Journal of Business and Psychology 25(4), 543-554.

SME Corporation Malaysia (2015) SMEs are important economic agents for Malaysia's growth.

Sun L-Y, S Aryee and KS Law (2007) High-performance human resource practices, citizenship behavior, and organizational performance: a relational perspective. The Academy of Management Journal 50(3), 558-577.

Takeuchi R, DP Lepak, H Wang and K Takeuchi (2007) An empirical examination of the mechanisms mediating between high-performance work systems and the performance of Japanese organizations. Journal of Applied Psychology 92(4), 1069-1083. 
Talukder A, M Vickers and A Khan (2018) Supervisor support and work-life balance: impacts on job performance in the Australian financial sector. Personnel Review 47(3), 727-744.

Tziner A and KR Murphy (1999) Additional evidence of attitudinal influences in performance appraisal. Journal of Business and Psychology 13(3), 407-419.

Valcour M, A Ollier-Malaterre, C Matz-Costa, M Pitt-Catsouphes and M Brown (2011) Influences on employee perceptions of organizational work-life support: signals and resources. Journal of Vocational Behavior 79(2), 588-595.

Whitener EM (2001) Do "high commitment" human resource practices affect employee commitment? A cross-level analysis using hierarchical linear modeling. Journal of Management 27(5), 515-535.

Wilder DA (1977) Perception of groups, size of opposition, and social influence. Journal of Experimental Social Psychology 13(3), 253-268.

Wong EL (2018) 32\% of fraud committed by senior management. The Edge Financial Daily.

Wong P-Y, NFA Bandar and J Saili (2017) Workplace factors and work-life balance among employees in selected services sector. International Journal of Business and Society 18(S4), 677-684.

Woodrow C and DE Guest (2014) When good HR gets bad results: exploring the challenge of HR implementation in the case of workplace bullying. Human Resource Management Journal 24(1), $38-56$. 